\title{
THE BIOMETHANE INJECTION INTO THE NATURAL GAS NETWORKS: THE EU'S GAS SYNERGY PATH
}

\author{
J. Savickis' ${ }^{1}$ L. Zemite ${ }^{2 *}$, N. Zeltins ${ }^{2}$, I. Bode ${ }^{2}$, L. Jansons ${ }^{2}$, \\ E. Dzelzitis², A. Koposovs², A. Selickis², A. Ansone² \\ ${ }^{1}$ ITERA Latvija \\ 50 Skanstes Str., Riga, LV-1013, LATVIA \\ ${ }^{2}$ Riga Technical University, \\ Faculty of Power and Electrical Engineering, Institute of Power Engineering \\ 12-1 Azenes Str., Riga, LV-1048, LATVIA \\ *e-mail: laila.zemite@rtu.Iv
}

Biomethane is one of the most promising renewable gases (hereafter - RG) - a flexible and easily storable fuel, and, when used along with the natural gas in any mixing proportion, no adjustments on equipment designed to use natural gas are required. In regions where natural gas grids already exist, there is a system suitable for distribution of the biomethane as well. Moreover, improving energy efficiency and sustainability of the gas infrastructure, it can be used as total substitute for natural gas. Since it has the same chemical properties as natural gas, with methane content level greater than $96 \%$, biomethane is suitable both for heat and electricity generation, and the use in transport.

Biomethane is injected into the natural gas networks of many Member States of the European Union (hereafter - the EU) on a regular basis for more than a decade, with the Netherlands, Germany, Austria, Sweden and France being among pioneers in this field. In most early cases, permission to inject biomethane into the natural gas grids came as part of a policy to decarbonize the road transport sector and was granted on a case-by-case basis. The intention to legally frame and standardise the EU's biomethane injection into the natural gas networks came much later and was fulfilled in the second half of the present decade.

This paper addresses the biomethane injection into the natural gas grids in some EU countries, highlights a few crucial aspects in this process, including but not limited to trends in standardisation and legal framework, injection conditions and pressure levels, as well as centralised biogas feedstock collection points and the biomethane injection facilities. In a wider context, the paper deals with the role of biomethane in the EU energy transition and further use of the existing natural gas networks.

Keywords: biomethane, injection, natural gas girds, renewable gases, synergy. 
During the energy transitions, the role of biomethane and other RGs in the EU is closely related to future prospects, and, to some extent, even physical survival of the natural gas infrastructure. Long-term strategies need to emerge in order to help secure the EU's energy future, as well as to add the diversification dimension to its energy security. Bearing in mind the limited timeframe of energy transition initiatives, which barely covers two decades, there is an urgent necessity to explore all possible synergy paths involving natural gas and RG across energy production, distribution, storage and consumption spectrum [1]-[3]. Among these paths, increasing presence of RGs, and, firstly and foremostly, biomethane in existing natural gas transportation and distribution networks should be studied more extensively.

The general trends of all deep decarbonisation strategies in the EU are centred around low-carbon energy systems as the backbone of the future energy supply, in which an expansion of renewable or maximally carbon neutral electricity generation is accompanied by widespread electrification of industrial processes. Electric heating takes over market share from the conventional natural gas in buildings, and e-mobility becomes more and more popular worldwide [4], [5]. Global investment in electricity generation, networks and storage in 2018 exceeded USD 770 billion, more than combined investment in oil and gas supply for the same period [6]. However, there are limits to how quickly and extensively electrification can develop, as it is not yet well suited to deliver all types of energy services. Even if the complete technical potential for electrification were deployed, there would still be sectors requiring other energy sources, including gaseous fuels.
Maintaining a parallel natural gas or $\mathrm{RG}$ infrastructure adds a layer of resilience compared with an approach that relies exclusively on electricity. This was rather obvious in Japan, when gas-fired generation stepped in to provide power after shutdown of its nuclear reactors following Fukushima Daiichi nuclear power plant disaster on 11 March 2011 [7]. It also provides a useful hedge against the risks that electrification and the development of new electricity networks do not increase at the pace needed to displace existing fuels while meeting energy service demands. However, if natural gas infrastructure is to secure the role in post energy transition EU, it will need to deliver much bigger share of $\mathrm{RG}$, one of which is biomethane. In a long run, the future of the natural gas infrastructure in the EU is largely dependent not only on diversification of gaseous fuel sources by gradually increasing percentage of RGs, but also on ability of the existing natural gas grids facilitate this diversity in a safe, cost effective and sustainable manner [8].

Increasing sustainability and carbon neutrality of the natural gas infrastructure all over the EU means more intensive presence of RGs into the natural gas sector. Here biomethane stands out as one of the most promising RGs to be blended with natural gas in large volumes, which can be done in a relatively short period of time [8]. Biomethane is a flexible and easily storable fuel that can be used wherever natural gas grids exist without significant improvements to any parts of the natural gas transportation and distribution networks. In those EU regions where a natural gas grid already exists, there is a system suitable for the distribution of biomethane as well. It can be used as a direct substitute for natural gas and as a fuel in heating, transport and electricity 
generation since it has the same properties as natural gas - achieving methane content levels greater than $96 \%$ [9]. However, this methane content level benchmark is not legally or technically binding to all the EU Member States, as they can make their own decisions on how pure biomethane must be in terms of methane content to be injected into the grid. For example, the Netherlands let biomethane with methane content of only $85 \%$ be injected, but Switzerland and Sweden require $96 \%$ and $97 \%$ of methane content [10].

Biomethane has been injected into the natural gas grids of many Member States of the EU for about a decade, with the Netherlands, Germany, Austria, Sweden and France being the pioneers in the field [11], [12]. In most early cases, however, permission to inject biomethane came as part of policy to attempt to decarbonize road transport only and was granted on a case-by-case basis. But, since 2003, Directive 2003/55/ EC of the European Parliament and of the Council of 26 June 2003 concerning common rules for the internal market in natural gas and repealing Directive 98/30/EC has granted the injection of gases from non-conventional sources into the natural gas network when technically possible and when safety is maintained. In period that followed Directive 2009/73/EC of the European Parliament and of the Council concerning common rules for the internal market in natural gas and repealing Directive 2003/55/EC (hereafter - Directive 2009/73/EC) and Directive 2009/28/EC of the European Parliament and of the Council on the promotion of the use of energy from renewable sources and amending and subsequently repealing Directives 2001/77/ EC and 2003/30/EC (hereafter - Directive 2009/28/EC) set out an all-EU legal framework for injection of biomethane into natural gas grids. Recital 26 of the preamble to
Directive 2009/73/EC states that Member States should take concrete measures to assist the wider use of biogas and gas from biomass, the producers of which should be granted non-discriminatory access to the gas system, provided that such access is compatible with the relevant technical rules and safety standards on an ongoing basis. Additionally, point (e), Article 40, of Directive 2009/73/EC also specifies that Member States should facilitate access to the network for new production capacity, in particular removing barriers that could prevent access for new market entrants and of gas from renewable energy sources [13].

Recital 62 of the preamble to Directive 2009/28/EC provides a further clarification on how new connections should be handled, as it states: the costs of connecting new producers of electricity and gas from renewable energy sources to the electricity and gas grids should be objective, transparent and non-discriminatory and due account should be taken of the benefit that embedded producers of electricity from renewable energy sources and local producers of gas from renewable sources bring to the electricity and gas grids. Article 16.7 and Article 16.9 of Directive 2009/28/EC also read that Member States shall ensure that the charging of transmission and distribution tariffs does not discriminate against gas from renewable energy sources, and that where relevant Member States shall assess the need to extend existing gas network infrastructure to facilitate the integration of gas from renewable sources [14].

The intention to standardise the EU's biomethane injection into the natural gas network came much later and was fulfilled in the second half of this decade. Part 1 of Standard EN 16723-2 "Natural gas and biomethane used in transport as well as biomethane injected into the natural gas network" (hereafter - Standard EN 16723-2) 
was published in 2016, and it concerned the requirements of biomethane injected into the natural gas grids [15]. Part 2, published in 2017, specifies the requirements and test methods for natural gas, biomethane and blends of both for use as vehicle fuels (standardisation applies to these fuels irrespective of the storage state (compressed or liquefied)) [16].

Standard EN 16723-2 includes the following general parameters:

- The natural gas, biomethane and blends of those intended for injection into natural gas networks shall be free from any constituents or impurities other than the ones described in this standard, to the extent that it cannot be transported, stored or utilized without quality adjustment or treatment. In the case of such other constituents and/or impurities, it may be necessary to obtain an approval from the competent and legitimate authority to define the acceptable risk in the territory of the injection point;

- Health criteria assessment for biomethane is complex and dependent upon the biogas feedstock and upgrading and purification process. As a result, it is recommended that contaminants to be specified and limits to be applied are assessed at national level using an appropriate methodology;

- Biomethane shall meet the requirements of the Standard EN 16726 "Gas infrastructure - Quality of gas - Group $\mathrm{H}$ for common parameters" that specifies gas quality characteristics, parameters and their limits, for gases classified as group $\mathrm{H}$ that are to be transmitted, injected into and from storages, distrib- uted and utilized [17].

At the national level, where access to the grid infrastructure is equal and nondiscriminatory, additional quality requirements have been set on biomethane and regasified LNG for injection into the natural gas grids (both transportation and distribution networks) [18].

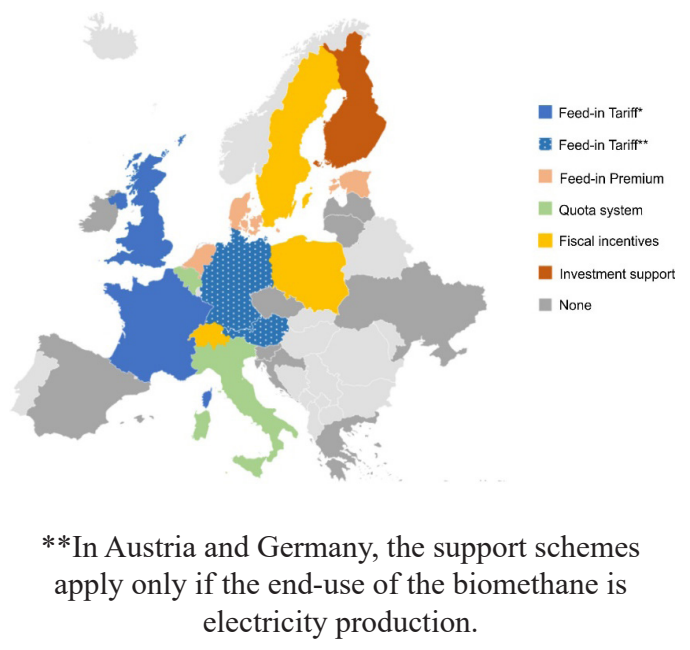

In Belgium, the support scheme is only applicable in Wallonia

Source: regatrace.eu

Fig. 1. Support schemes in place per country.

Several different subsidy or market schemes in the field of biomethane are used in the European countries, which include but are not limited to tax exemptions, feedin tariffs, investment subsidies or grants, preferential financial conditions for loans, reduction or exemption of grid tariffs, obligation of grid operator to take over connection costs, exemption for penalties for balance energy and quota systems [19]. Figure 1 shows the current variety of the biomethane production support schemes in Europe.

\section{SEVERAL TRENDS OF BIOMETHANE SECTOR DEVELOPMENT IN THE EU}

In Europe landfill and sewage gases account for around a quarter of total biogas 
production, while most of the resources come from another source: anaerobic fermentation of agricultural feedstock. Up to $70 \%$ of the feedstocks - such as energy crops, manure and agricultural residues used for biogas production - emerges from the agricultural sector [20]. The use of agricultural residues is particularly important in countries like Denmark, France and Italy, but energy crops are mainly grown and used in Germany and Austria. The municipal and industrial organic waste still has a potential to be developed for use in biogas production, like it is done in the Nordic countries [21].

By the end of 2012 biogas was upgraded to biomethane in eleven EU countries, and in nine countries it was injected into the natural gas grids. Sweden and Switzerland have the longest experience with biomethane injection into natural gas distribution networks and closed local networks, which started back in the 1990s [22]. In 2018, the European countries with the biggest production of the renewable gases, mostly biomethane, were Germany with $10018 \mathrm{GWh}$, the United Kingdom with $3300 \mathrm{GWh}$, the Netherlands with 2226 GWh, Denmark with $1425 \mathrm{GWh}$, Sweden with $1281 \mathrm{GWh}$ and France with 1207 GWh. Apart from Sweden and Germany, no country reported production of renewable gases via gasification or power-to-methane process. Sweden reported gasification production of $15 \mathrm{GWh}$ in 2018, but renewable gas production in Germany via gasification or power-tomethane was negligible [23].

As the leading biogas producing region, the EU has around 20000 biogas plants, with the majority of them located in Germany. Most are built for on-site electricity generation and co-generation, with around 500 plants dedicated to the upgrading of biogas [8]. The analysis of the latest data shows that the number of the biomethane plants in Europe has increased by $51 \%$ in 2 years, from 483 in 2018 to 729 in 2020. There are currently eighteen countries producing biomethane in Europe. Germany has the highest share of biomethane production plants (232), followed by France (131) and the United Kingdom (80) [24].

The biomethane production in Germany begun in 2006, and since then, the number of biomethane plants and the total annual production capacity have been growing constantly. In 2018, the number of plants reached 213 units, but in $2020-$ 232 units with approximately $10 \mathrm{TWh}$ of yearly maximum biomethane output capacity [23]. Theoretically, the whole amount of biomethane produced in Germany can be injected into the natural gas grids, with costs for the injection shared between the plant operator and the gas grid operator in the proportion $25 \%$ to $75 \%$. Moreover, if the length of the connecting pipelines is less than $1000 \mathrm{~m}$, share of the biomethane plant operator must not exceed EUR 250 000, but if connecting pipelines are longer than $10 \mathrm{~km}$, the plant operator bears additional costs. The connecting pipelines, including the injection unit, are normally a property of the gas grid operator [23].

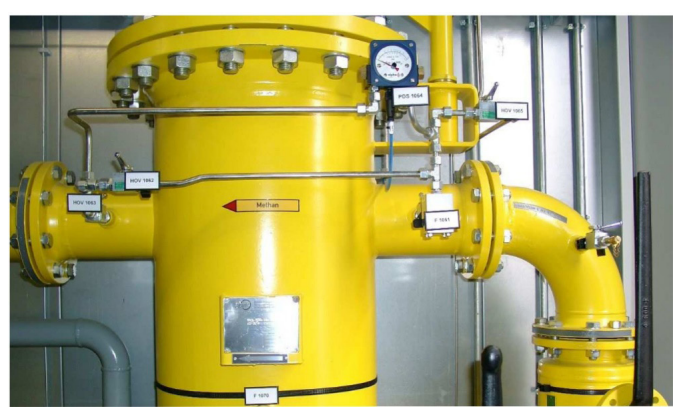

Fig. 2. Biomethane piping and measurement equipment in the grid connection station, Germany.

Source: dena.de 
France is one of a few EU countries that has specific biomethane target: to produce 8 TWh of biomethane by 2023. Biomethane was granted regular access to the natural gas grids only in 2011, and after this date the growth in a field was considerable, with the number of new biomethane plants going from 7 to 107 between 2015 and 2019. According to an overview of France's renewable gas sector, the amount of biomethane injected into the French natural gas networks almost doubled between 2016 and 2017. Figures in the report from GRTgaz show that 406 million $\mathrm{kWh}$ of RGs were injected into the network over this period, which is equivalent to the consumption of nearly 34000 homes [25].

Around 100 new biomethane projects were declared in France in 2017 alone, increasing the biomethane production capacity by 3 billion $\mathrm{kWh} /$ year. With a total of 361 biomethane projects registered, the country's prospected total capacity now stands at 8 billion $\mathrm{kWh} /$ year. The growth of the biomethane sector strengthens the role of the agricultural sector in France's economy, while also helping to develop a competitive industrial sector [26].

Over 1000 projects are currently at different stages of development, meaning that France is fulfilling its ambition to become a leader in the European biomethane sector by the mid and late 2020s [23].

An analysis of the biomethane life cycle carried out by the gas distribution system operator (hereafter - DSO) GRDF demonstrated that the development of the biomethane sector could prevent emission of 750000 tonnes of $\mathrm{CO}_{2}$ for the year 2020 alone. Cumulatively, the emission of over 2 million tonnes of $\mathrm{CO}_{2}$ would therefore be avoided thanks to the development of the biomethane sector between 2018 and 2020. In other words, for each MWh of biomethane produced, injected and consumed, sav- ings of 188 kilogrammes of $\mathrm{CO}_{2}$ equivalent would be made. The French Environment \& Energy Management Agency anticipates that 500 to 1400 plants could inject between 12 and $30 \mathrm{TWh} /$ year of biomethane into the natural gas transportation and distribution networks around 2030 [27].

In the United Kingdom, biomethane is already being injected into the gas grid at a number of biogas upgrading facilities: for example, in "AB Agri" anaerobic digestion plant in North Yorkshire, which has the capacity to process 60000 tonnes of waste a year. At the same time, its EU Member State neighbour - Ireland - plans to achieve $20 \%$ renewable gas in the natural gas network by 2030. To achieve this ambitious goal, its first biomethane injection facility was built in Nurney, Kildare, and the first portion of biomethane was injected into the grid in 2019. In upcoming years, it is planned to implement a network of injection facilities throughout Ireland [28].

In most cases, national production and consumption of biomethane are well balanced, and currently only some EU countries demonstrate slight disbalance between the two. For instance, as shown in Fig. 3, Denmark is producing more biomethane than it consumes, whereas Sweden is consuming more than double the amount it is producing. This is mainly because in Sweden incentives are focused on the consumption side, of which tax exemption is the most important one, whereas in other EU Member States subsidies are focused on production or injection of biomethane. It means that imported biomethane in Sweden can be double subsidized. In 2016, Sweden imported 200 GWh from Denmark, which increased to $1132 \mathrm{GWh}$ in 2018. At the same time, in Germany production of biomethane in 2018 was 1498 GWh higher than its consumption. Germany exported some of these resources to the Netherlands 
and Switzerland, but the biggest share of leftover biomethane is still stored in the natural gas grids for later use [23].

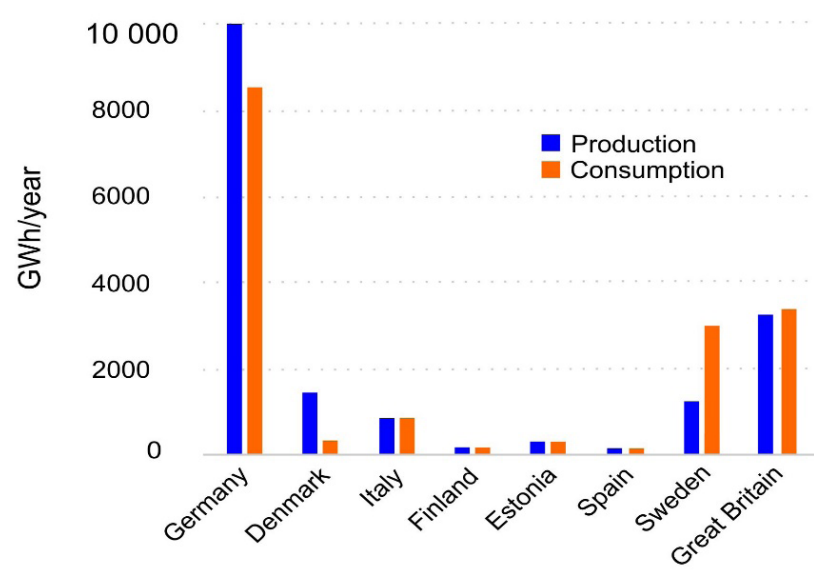

Fig. 3. Biomethane production compared to total biomethane consumption (per country, GWh/year).

Source: regatrace.eu

If there is a successful introduction of gasification, optimal use of anaerobic digestion potential and options for cross-border trade, volumes of the biomethane injected into the EU natural gas grids could reach up to $10 \%-20 \%$ of all gaseous fuel consumption. Even more, the estimates have been made that during energy transition, biomethane could provide total gradual replacement of the conventional natural gas in the so-called mature gas markets, such as the United Kingdom, Germany and the Netherlands [29].

\section{THE CASE OF LATVIA}

Latvia has biogas production, but biomethane upgrading and its injection into the natural gas grids are still absent. At the same time, the legal and regulatory framework for injection of biomethane into the natural gas grids is already in place. Namely, paragraphs 6 and 7 of Regulation of the Cabinet of Ministers No. 650 "Requirements for the Injection and Transport of Biomethane and Gaseous Liquefied Natural Gas in the Natural Gas Transmission and Distribution System" (hereafter - Regulation No. 650) clearly state that in Latvia injection of biomethane is possible in both natural gas transmission and distribution networks. If biomethane is injected into the natural gas transmission system, where a minimum pressure is 25 bar, its pressure must not exceed the actual pressure of the system by more than 5 bar. On the other hand, if biomethane is injected into the natural gas distribution system, its operating pressure must exceed the pressure of the system by not more than $10 \%$ of the actual pressure at the connection point. The Appendix of Regulation No. 650 also shows the purity or chemical composition requirements that must be met in order to inject biomethane into the natural gas systems [18]. 
Table 1. Quality Characteristics of the Substitute Gas to be Injected and Transported in the Natural Gas Transmission and Distribution System

\begin{tabular}{|c|c|c|}
\hline Parameter & Unit & Value \\
\hline $\begin{array}{l}\text { Wobbe index - WI, b at base temperature conditions (combustion / } \\
\text { measurement) } 25 / 20{ }^{\circ} \mathrm{C}\end{array}$ & $\begin{array}{l}\mathrm{MJ} / \mathrm{m}^{3} \\
\mathrm{kcal} / \mathrm{m}^{3} \\
\mathrm{kWh} / \mathrm{m}^{3}\end{array}$ & $\begin{array}{l}47.02-51.98 \\
11231-12415 \\
13.06-14.44\end{array}$ \\
\hline $\begin{array}{l}\text { Maximum heat of combustion (GCV) at a base temperature of } 20^{\circ} \mathrm{C} \\
\text { and } 101.325 \mathrm{kPa} \text { (combustion / measurement) } 25 / 20^{\circ} \mathrm{C}\end{array}$ & $\begin{array}{l}\mathrm{MJ} / \mathrm{m}^{3} \\
\mathrm{kcal} / \mathrm{m}^{3} \\
\mathrm{kWh} / \mathrm{m}^{3}\end{array}$ & $\begin{array}{l}\geq 34.87 \\
\geq 8329 \\
\geq 9.69\end{array}$ \\
\hline $\begin{array}{l}\text { Minimal heat of combustion (GCV) at a base temperature of } 20^{\circ} \mathrm{C} \\
\text { and } 101.325 \mathrm{kPa} \text { (combustion / measurement) } 25 / 20^{\circ} \mathrm{C}\end{array}$ & $\begin{array}{l}\mathrm{MJ} / \mathrm{m}^{3} \\
\mathrm{kcal} / \mathrm{m}^{3} \\
\mathrm{kWh} / \mathrm{m}^{3}\end{array}$ & $\begin{array}{l}\geq 31.82 \\
\geq 7600 \\
\geq 8.83\end{array}$ \\
\hline Relative density $-\mathrm{d}$ & & $0.55-0.70$ \\
\hline Total sulfur - S (without odorant) & $\mathrm{g} / \mathrm{m}^{3}$ & $\leq 0.03$ \\
\hline Hydrogen sulfide + carbonyl sulfide $\mathrm{H}_{2} \mathrm{~S}+\mathrm{COS}$ & $\mathrm{g} / \mathrm{m}^{3}$ & $\leq 0.007$ \\
\hline Mercaptans - RHS (without odorant) & $\mathrm{g} / \mathrm{m}^{3}$ & $\leq 0.016$ \\
\hline Methane $-\mathrm{CH}_{4}$ & mol \% & $\geq 90$ \\
\hline Nitrogen $-\mathrm{N}_{2}$ & mol \% & $\leq 3$ \\
\hline Oxygen $-\mathrm{O}_{2}$ & $\operatorname{mol~\% ~}$ & $\begin{array}{l}\leq 0.02 * \\
\leq 1.0 * *\end{array}$ \\
\hline Carbon dioxide $-\mathrm{CO}_{2}$ & $\operatorname{mol~\% ~}$ & $\begin{array}{l}\leq 2.5^{*} \\
\leq 4.0^{* *}\end{array}$ \\
\hline Methane number & & $\geq 65$ \\
\hline Mechanical impurities & $\mathrm{g} / \mathrm{m}^{3}$ & $\leq 0.001$ \\
\hline The hydrocarbon dew point HC DP, pie 1-70 bar & ${ }^{\circ} \mathrm{C}$ & $\leq-2$ \\
\hline The water dew point H2O DP, pie 40 bar & ${ }^{\circ} \mathrm{C}$ & $\leq-10$ \\
\hline Hydrogen $-\mathrm{H}_{2}$ & mol \% & $\leq 0.1$ \\
\hline Odorant & $\begin{array}{l}\mathrm{mg} / \mathrm{m}^{3} \\
\text { points }\end{array}$ & $\begin{array}{l}\geq 3 \\
\geq 3\end{array}$ \\
\hline
\end{tabular}

* Quality characteristics of the substitute gas to be fed into and transported in the natural gas transmission system.

** Quality characteristics of the substitute gas to be fed into and transported in the natural gas distribution system, if the distribution system is not connected to the underground gas storage and is not connected to the gas supply system of other countries.

In both cases, the supply of biomethane to the gas pipelines of the natural gas transmission system must take place in such a way that the requirements of the natural gas transmission system operator regarding the supply/mixing point are met [18].

Latvia has a significant potential for development of biomethane injection into the natural gas grids, but it has not been started yet. There are 59 biogas plants in operation in Latvia, and in most cases bio- gas is used locally - for the production of electricity. However, according to present estimates, production of biomethane with its subsequent injection into the natural gas grids would be a more cost-effective option in terms of economy and sustainable transformation of the natural gas sector [2].

About $12 \%$ of Latvia's biogas plants rely on landfill resources for biogas production, $2 \%$ are sewage sludge substrate biogas plants, $5 \%$ are plants producing biogas 
from produce residues or wastewater, and the major share $-81 \%$ - run on agricultural waste. Figure 4 shows biogas plant proximity to the natural gas grids, and most of them are located rather close to both natural gas transport and distribution networks. Injec- tion of biogas into those grids is currently prevented by quite a few obstacles, like private land ownership, rough terrains and lack of clearly defined and transparent support schemes, and in future these obstacles should be adequately addressed [2].

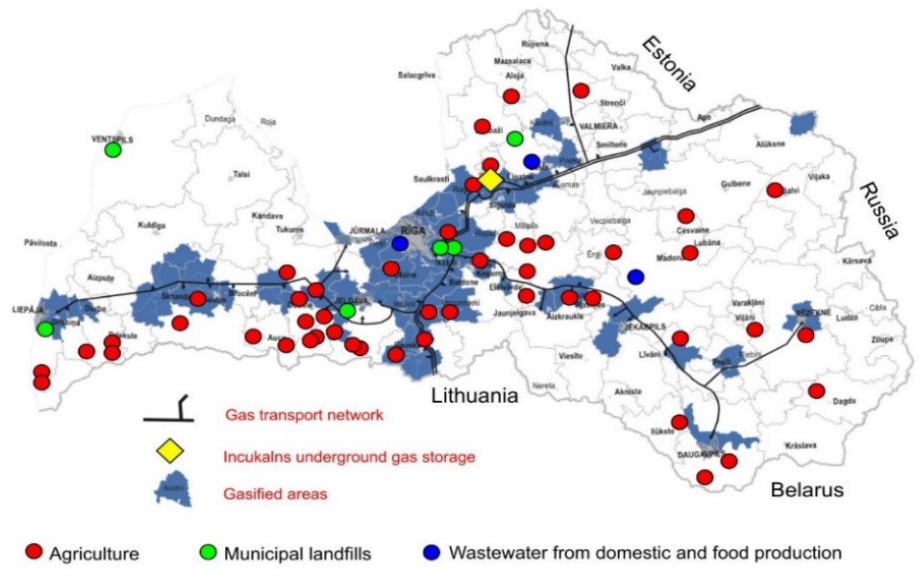

Fig. 4. Location and type of biogas plants in Latvia with respect to the natural gas network.

Source: JSC "Gaso", the Latvian Biogas Association

The comparative research has been made, which established that on average the Latvian biogas plants operate at between $60 \%$ and $70 \%$ of installed capacity rate. Only twenty-three out of fifty-nine plants have average operational capacity of $80 \%$ or more, and almost the same number nineteen plants - have average operational capacity of less than $50 \%$. The remaining biogas plants operate at average capacity between $50 \%$ and $80 \%$. If the connections between biogas plants and the natural gas grids are constructed where possible and economically feasible, they could be used not only for transportation of biomethane from plants to grid, but also, if necessary, for delivery of natural gas to the plants, thus ensuring the maximum productivity of cogeneration facilities. If distance from a biogas plant to a possible connection point with the natural gas distribution grid is considered the main criterion, seventeen biogas plants can relatively easily be connected to grids, as five of them are located less than $1 \mathrm{~km}$, nine are located less than $5 \mathrm{~km}$ and three - up to $10 \mathrm{~km}$ away from the natural gas grid. Another seven plants are located within 10 to $15 \mathrm{~km}$ distance from possible grid connection points, and at the moment it is rather questionable whether their connection to the grids would be technically and financially feasible. Additionally, all these distances can deviate by about $10 \%$, as actual, precise measurements are taken.

As for five plants located less than $1 \mathrm{~km}$ to the natural gas grid, their total installed cogeneration capacity is $3.72 \mathrm{MW}$ and, they have an average operational capacity rate of $78 \%$. While operating at a maximum capacity rate of $95 \%$, the amount of energy 
produced there is about $30950 \mathrm{MWh}$, with possible additional electricity production of $6735 \mathrm{MWh}$. For approximate calculation of the connection costs, the natural gas flows and approximate pipeline diameters were estimated. The natural gas pipeline connection flows range from 63 to $141 \mathrm{~m}^{3} / \mathrm{h}$, but mostly are above $280 \mathrm{~m}^{3} / \mathrm{h}$. The required nominal diameters of connection pipelines therefore are $32 \mathrm{~mm}$ to $50 \mathrm{~mm}$. The approximate total costs of the pipelines and gas control points are estimated at EUR 188 247. Assuming that the plants, when operating at $70 \%$ capacity rate, are upgrading all produced biogas to the biomethane level and injecting it into the natural gas grids, the specific current biogas purification costs for three closest plants would be around 0.132 $\mathrm{EUR} / \mathrm{m}^{3}$, and for two - around 0.204 EUR/ $\mathrm{m}^{3}$. The total estimated cost of construction, including pipelines, gas control points and injection facility, for plants up to $1 \mathrm{~km}$ from the natural gas distribution network would reach about EUR 2947114.

Fourteen biogas plants within a distance of up to $5 \mathrm{~km}$ from the natural gas grids with total installed cogeneration capacity of 16.09 MW operate at an average capacity rate of $64 \%$. In this case, if the plants operated with the maximum capacity rate of $95 \%$, the amount of electricity produced would reach about $133859 \mathrm{MWh}$. The required nominal diameters for connection pipelines range from 25 to $100 \mathrm{~mm}$, with average diameter of $<65 \mathrm{~mm}$. The estimated cost for the pipeline and gas control point construction is about EUR 1698 000, but the estimated cost of installation of the biogas upgrading facility - EUR 12603000 .

Seventeen biogas plants with a distance of up to $10 \mathrm{~km}$ to the natural gas grid with total installed cogeneration capacity of 18.33 MW operate at an average capacity rate of $65 \%$. If plants operated at a maximum capacity rate, the possible amount of electricity produced would be 152542 MWh. In order to make connection with the natural gas grid, the required nominal diameters of pipelines in this case again range from 25 to $100 \mathrm{~mm}$. The approximate cost of the pipelines and gas control points is EUR 2871 991, but the total estimated cost of the project, including biomethane production facility, is EUR 15113551.

Twenty-four biogas plants within a distance of up to $17 \mathrm{~km}$ to the natural gas grid with the total installed cogeneration capacity of $24.87 \mathrm{MW}$ operate at an average capacity rate of $69 \%$ and produce about 142938 MWh of electricity. The maximum possible amount of electricity produced during the year is 206960 MW. By constructing gas pipeline connections, thus ensuring maximum cogeneration productivity, it is possible to produce additional $64022 \mathrm{MWh}$ of electricity per year. The total estimated cost of the pipelines and gas control points is EUR 7735 419, but construction of the biogas upgrading facility - 28492525 EUR.

As a result, the conclusion was drawn that for plants located 5-10 km from the natural gas grids, the cost of the pipeline connection was on average 7 times lower than the cost of biogas upgrading technology. The construction costs of the natural gas connection would begin to dominate over the costs of the upgrading facility only when the length of the natural gas connection would reach:

- $25 \mathrm{~km}$, and the plant capacity would be $250 \mathrm{~m}^{3} / \mathrm{h}$;

- $\quad 30 \mathrm{~km}$, and the plant capacity would be 500,650 and $950 \mathrm{~m}^{3} / \mathrm{h}$;

- $\quad 35 \mathrm{~km}$, and the plant capacity would be $1400 \mathrm{~m}^{3} / \mathrm{h}$;

- $45 \mathrm{~km}$, and the plant capacity would be $2000 \mathrm{~m}^{3} / \mathrm{h}$.

The introduction of centralised points 
to produce or inject biomethane into the natural gas grid is quite promising option, especially in areas with rather dense clustering of biogas plants, which could have particular advantage in countries such as Latvia. Centralised biomethane injection points could provide a relatively easy and less costly alternative to installing separate injection points for numerous producers. It would facilitate biomethane production particularly in places where separate, direct connections of the distributed biogas plants are not feasible due to technical or other reasons [30].

There are two principal options to organise centralised biomethane injection into the natural gas grids. The first option is a centralised feedstock collector, where separate producers of biogas feedstock deliver the raw product. Digestion, scrubbing and injection would be all carried out at this central location for multiple producers. This option is favourable, if biogas producers are not interested in the development of full-scale biogas production and consumption of their respective sites, or they have access to large stock of raw products, which can be split between biogas production and consumption on site and raw material delivery to a centralised feedstock facility. This possibility would be especially interesting in regions, where there are no full-scale biogas plants, or to farmers, who produce large amount of agricultural waste with no intension to invest in separate biogas production.
However, estimates made by some research groups show little financial benefit in centralised biogas production [30].

The second option is to establish a centralised biogas upgrade and injection facility, where all the delivered biogas is treated and scrubbed to convert it to biomethane and then injected into the natural gas grid [31]. Producers of biogas would deliver their product to a centralised facility via pipelines or by specialised gas carrier trucks [32]. If gas carrier trucks are used to transport biomethane to a centralised facility, it would need to be compressed and collected from multiple sites according to a certain schedule, but, if pipeline connections are installed between a centralised facility and separate biogas plants, such a schedule would not be required.

In many cases, overall capital and operating costs for centralised biomethane injection points would be lower per unit of biomethane injected, and it would be easier to monitor biomethane quality and enforce safety standards. If such injection points were available, it could lead to more interest in biomethane production and its distribution via the natural gas grids in Latvia. Needless to add that with correctly balanced incentives, biomethane is a commercially viable transport fuel as well: it can rely on existing natural gas infrastructure and contribute to reaching the European climate targets in reduction of $\mathrm{CO}_{2}$ and other greenhouse gas emissions [20].

\section{THE PRINCIPLES OF BIOMETHANE INJECTION INTO THE NATURAL GAS GRID}

The technical rules and legislative framework of injection of biomethane into the natural gas grids vary in different EU Member States, and responsibilities are attributed to the different parties, including but not limited to regulatory authorities, energy suppliers, biogas producers, natural gas transmission system operators 
(TSOs), DSOs and the third parties. The owners or operators shall be clearly defined for biogas upgrading and compression unit, biomethane injection facilities and biomethane quality control systems (chemical composition monitoring, metering, etc.). The following responsibilities should also be allocated between the different parties: the biogas production environmental safety control, the compliance with the technical specifications which correspond to the injection conditions, odorization and deodorization of biomethane (when necessary), obligation to informing the adjacent TSOs, natural gas storage system operators and customers that they may be supplied with biomethane [33].

In order to supply information to policy makers, interested parties, potential customers and society at large on the biomethane production status in a certain country or region, the 2020 edition of biomethane map suggests adding three more points to a regular information list, which are:

- the type of connection to the grid: some biomethane plants are connected to the natural gas transport grid, others to the distribution grid, and a few are not connected as they use biomethane for their own consumption;

- the type of gas transported in a specific grid: it depends on national specifications and can be low caloric or high caloric (does not apply to Latvia);

- availability of on-site production of bioCNG or bio-LNG, which can be used as an all-purpose sustainable fuel [24].

The natural gas transmission system, transporting large volumes of the natural gas at high pressure, is the main element of every national or regional natural gas grid. The physical characteristics of the transmission system vary for technical or safety reasons with pipeline diameters in most cases from DN80 up to DN1400 and a natural gas pressure between approximately 16 bar up to the maximum operating pressure of 50 bar and higher [33].

High-power compression plants ensure that there is sufficient pressure in the system to deliver natural gas to all parts of the network in order to meet the daily demand. Biomethane injected at the transmission level, therefore, must be at a higher pressure than that injected at the distribution level [18]. Accordingly, its compression costs would be higher for the producers injecting into the transmission system. Theoretically, it might be possible to accept at the transmission level small volumes of biomethane, which do not meet the normal natural gas quality standards, as small quantities of such biomethane would be mixed with a much larger volume of standard quality natural gas, resulting in dilution of impurities present in RG. However, in ordinary circumstances, biomethane purity requirements must be met at all times and regardless of amount of biomethane injected into the grids. Table 2 lists the main contaminants of biogas that should be maximally removed from biomethane before its further use.

Odorization may not be necessary if the quantities being injected are small relative to the volumes of natural gas in the transmission system, which is already odorised, and this could result in some operational savings for biomethane producers. In some European countries, the distribution systems require odorization only at quite low pressures - for instance, in Great Britain natural gas must be odorized when delivered at 7 bar or lower [34].

There are very few situations, when it is justified to require biomethane injection into the grid at the transmission level, and these cases are normally dealt with individually. In the future, if there are numerous 
large-scale biomethane upgrading facilities to this option more regularly. coming online, it may be necessary to turn

Table 2. Contaminants of Biogas, Their Sources and Impact on Plant Operation

\begin{tabular}{|c|c|c|}
\hline Impurity & Source & Impact \\
\hline $\begin{array}{l}\text { Carbone dioxide - } \\
\mathrm{CO}_{2}\end{array}$ & $\begin{array}{l}\text { Mineralization of carbon } \\
\text { from organic biomass (the } \\
\text { main component of biogas) }\end{array}$ & $\begin{array}{l}\text { Reduces overall calorific value; promotes corrosion of } \\
\text { metallic parts by formation of weak carbonic acid }\end{array}$ \\
\hline $\begin{array}{l}\text { Hydrogen sulfide - } \\
\mathrm{H}_{2} \mathrm{~S}\end{array}$ & $\begin{array}{l}\text { Proteins, manure, organic } \\
\text { waste }\end{array}$ & $\begin{array}{l}\text { Acts as corrosive in pipelines; causes } \mathrm{SO}_{2} \text { emissions } \\
\text { after combustion or } \mathrm{H}_{2} \mathrm{~S} \text { emissions in case of incom- } \\
\text { plete combustion; poisons the catalytic convertor }\end{array}$ \\
\hline Water $-\mathrm{H}_{2} \mathrm{O}$ & & $\begin{array}{l}\text { A major contributor to corrosion in aggregates and } \\
\text { pipelines by forming acid with other compounds; for- } \\
\text { mation of condensation leading to the damage of instru- } \\
\text { ments; freezing of accumulated water in high-pressure } \\
\text { low temperature conditions }\end{array}$ \\
\hline Ammonia $-\mathrm{NH}_{3}$ & Proteins & $\begin{array}{l}\text { Leads to an increase in antiknock properties of engines; } \\
\text { causes formation of } \mathrm{NO}_{\mathrm{x}} \text {. }\end{array}$ \\
\hline Dinitrogen $-\mathrm{N}_{2}$ & $\begin{array}{l}\text { Air input, e.g., by desul- } \\
\text { phurization with air }\end{array}$ & $\begin{array}{l}\text { Leads to an increase in antiknock properties of engines; } \\
\text { leads to a reduction in calorific value as well }\end{array}$ \\
\hline Siloxanes & $\begin{array}{l}\text { Cosmetics, antifoaming } \\
\text { agents, washing agent, } \\
\text { hydraulic fluent }\end{array}$ & $\begin{array}{l}\text { They are mainly present in biogas formed out of landfill } \\
\text { or sewage gas. This hydrocarbon acts as quartz of } \\
\text { silica, grinding motor part }\end{array}$ \\
\hline Dust & & Damages vents and exhaust by clogging \\
\hline
\end{tabular}

Source: dena.de

From the practical standpoint, it is more likely, that biomethane plants would connect to the natural gas distribution systems, which is a common practice in the EU countries [35]. The natural gas distribution system operates at a lower pressure and is designed to move smaller volumes of gas than the transmission system. Many natural gas distribution pipelines in the European countries feed residential customers and small businesses, where natural gas use is weather dependent and, therefore, has very low demand in summer months [36]. In small, strictly localized systems, if quantities of the biomethane injected exceeded the demand of distribution system and could not physically take the gas away from the injection point, pressures would rise and this could pose a safety risk in the pipeline where biomethane was injected. The minimum demand levels on the distribution network, therefore, limit the size of the biomethane plant or amount of simultaneous injection capacity that can be accommodated at any particular point on the networks [37]. As experience shows, in some countries only the biomethane facilities that have their own gas storages on site [38] may be permitted to connect to the distribution pipelines where the minimum demand level is very low. For instance, it is a practice in Great Britain that biomethane plants are limited in size to the minimum demand levels of the downstream pipeline. Areas where direct connection is most costeffective must have some or all of the following criteria: proximity to the distribution network and proximity to year-round 
gas consumption points (industrial estates, hospitals, swimming pools, sport and community centres etc.). Parts of the natural gas distribution network that currently require reinforcement could especially benefit from the addition of the local biomethane injection.

The cases of biomethane injection at both transportation and distribution levels in pipelines, which are connected to under- ground storages, should be treated separately, as storage system operators should give their own specifications, if different from general requirements of biomethane injection into the grid. In most EU countries, currently there are no formal limitations for biomethane injection into the grids with subsequent placement in different types of gas storages.

\section{CONCLUSION}

The current state of development of the biomethane sector in the European countries, including the EU Member States, and corresponding legislative frameworks are rather various. Many countries treat biomethane as a viable alternative for raw biogas plants, as it can decarbonise the natural gas grids and trigger energy transition at the natural gas infrastructure level. For most countries, production and consumption of biomethane are well balanced, but crossborder trade - rather limited [23].

As for Latvia, injection of biomethane into the natural gas grids can bring a valid option for decarbonisation of the natural gas supply chain and provide local, renewable resources with wider market accessibility [2]. Among biogas plants currently in operation in Latvia, five are located within $1 \mathrm{~km}$ radius around possible gas grid connection points, nine - within $5 \mathrm{~km}$ radius and three - within $10 \mathrm{~km}$ radius. Additional seven biogas plants are located between 10 and $15 \mathrm{~km}$ distance around the natural gas grids. Biomethane injection legally can be performed both in the natural gas transportation and distribution networks [18].

The most promising connections can be built with the biogas plants located within $10 \mathrm{~km}$ radius; thus, costs of the pipeline connections tend to grow significantly in comparison with biomethane injection facility costs, when biogas plants are located further than $10 \mathrm{~km}$ around the natural gas grid. At the same time, centralised biomethane injection can be a viable solution for regionally clustered biogas plants, where owners are not willing to subsidise separate biomethane upgrading and injection projects.

Benefits from biomethane injection into the natural gas grid in Latvia include:

- liquidation of biogas "locality": use of raw biogas in Latvia relates exclusively to electricity generation on-site, where leftover heat energy is rarely utilised at all. If biogas is upgraded to the level of biomethane, it can be used anywhere: for instance, in efficient modern domestic gas boilers or remote modern microCHPs, allowing one to improve overall efficiency of biomethane up to $90 \%$;

- support of the "green gas" delivery to every household and business customer: effective and widespread delivery of renewable fuel and heat, as biomethane injection into the natural gas grid enables renewable resources to reach over 444400 homes in Latvia, where natural gas is physically available. The same applies to all scale business customers; 
- more active market participation: injection of biomethane into the natural gas grid gives a producer direct access to a much larger spectrum of potential clients than if biomethane was to be sold and used only locally. From the perspective of the biogas producer, injecting biomethane into the natural gas grid can, therefore, give access to a higher price than available locally. Depending on commercial factors, including the associated costs, this may mean a higher net price.

- returning biogas from "electricity domain" to "gas domain": a vast major- ity of the local biogas projects were created and are actively used as a source of subsidised electricity production, which means that, unlike many EU countries, in Latvia the biogas sector focuses only on electricity, without much interest to turn to RGs. The fiscal incentives or other support schemes should be developed in order to trigger the biomethane production with its subsequent injection into the natural gas grid. This is one of the most viable ways to ensure the gas synergy for sustainable future of the existing natural gas infrastructure in Latvia.

\section{ACKNOWLEDGEMENTS}

The research has been supported by the National Research Programme, project "Trends, Challenges and Solutions of Lat- vian Gas Infrastructure Development" (LAGAS) (No. VPP-EM-INFRA-2018/10003).

\section{REFERENCES}

1. Wellinger, A., Murphy, J., \& Baxter, D. (2013) The Biogas Handbook: Science, Production and Applications. Elsevier.

2. Savickis, J., Zeltins, N., \& Jansons, L. Synergy between the Natural Gas and RES in Enhancement of Security of Energy Supply in the Baltic Countries (Problem Statement). Latvian Journal of Physics and Technical Sciences, 56 (6). DOI: https://doi. org/10.2478/lpts-2019-0032

3. International Energy Agency. (2019). The Role of Gas in Today's Energy Transitions. World Energy Outlook Special Report.

4. Herring, H. (2012). Living in a Low-Carbon Society in 2050. Springer.

5. Lombardi, P., \& Gruenig, M. (ed.). (2016). Low-carbon Energy Security from a European Perspective. Academic Press.

6. International Energy Agency. (2019). World Energy Investment 2019. [Online].
[Accessed: 12 June 2020] https://www. connaissancedesenergies.org/sites/default/ files/pdf-actualites/WEI2019.pdf

7. Vivoda, V. (2016) Energy Security in Japan: Challenges after Fukushima. Routledge.

8. Outlook for Biogas and Prospects for Organic Growth. World Energy Outlook Special Report Biomethane. (2020). [Online]. [Accessed: 12 July 2020] https:// www.euneighbours.eu/sites/default/files/ publications/ 202003/Outlook_for_biogas and_biomethane.pdf

9. European Biogas Association. (n.d.). EBA's Biomethane Fact Sheet. [Online]. [Accessed: 20 March 2020] https://www. europeanbiogas.eu/wp-content/uploads/ files/2013/10/eba_biomethane_factsheet. pdf

10. Koonaphapdeelert, S., Aggarangsi, P., \& Moran, J. (2020). Biomethane: Production and Applications. Springer. 
11. Raboni, M., \& Urbini, G. (2014). Production and Use of Biogas in Europe: A Survey of Current Status and Perspectives. Rev. Ambient. Água, 9 (2). Apr./June 2014. https://doi.org/10.4136/ambi-agua.1324.

12. Etudes de l'Ifri. (2019). Biogas and Biomethane in Europe. Lessons from Denmark, Germany and Italy. [Online]. [Accessed: 20 May 2020] https://www.ifri. $\mathrm{org} / \mathrm{sites} / \mathrm{default} /$ files/atoms/files/mathieu eyl-mazzega biomethane_2019.pdf

13. Directive 2009/73/EC of the European Parliament and of the Council of 13 July 2009 concerning common rules for the internal market in natural gas and repealing Directive 2003/55/EC. [Online]. [Accessed: 20 June 2020] https:// eur-lex.europa.eu/legal-content/EN/ ALL/?uri=CELEX\%3A32009L0073

14. Directive 2009/28/EC of the European Parliament and of the Council of 23 April 2009 on the promotion of the use of energy from renewable sources and amending and subsequently repealing Directives 2001/77/EC and 2003/30/ EC. [Online]. [Accessed: 16 June 2020] https://eur-lex.europa.eu/legal-content/EN/ ALL/?uri=CELEX\%3A32009L0028

15. EN 16723-1:2016. Natural gas and biomethane for use in transport and biomethane for injection in the natural gas network-Part 1: Specifications for biomethane for injection in the natural gas network. [Online]. Accessed: 10 July 2020] https://infostore.saiglobal.com/engb/Standards/EN-16723-1-2016-342125 SAIG_CEN_CEN_783563/

16. EN 16723-2:2017. Natural gas and biomethane for use in transport and biomethane for injection in the natural gas network-Part 2: Automotive fuel specifications.

17. Report on the practical experiences with the application of European Biomethane Standards. (2017). [Online]. [Accessed: 5 July2020]http://www.ergar.org/wp-content/ uploads/2018/07/BIOSURF-D3.7.pdf

18. Ministru kabineta noteikumi Nr. 650. (prot. Nr. 50 5. §) "Prasības biometāna un gāzveida stāvoklī pārvērstas sašķidrinātās dabasgāzes ievadīšanai un transportēšanai dabasgāzes pārvades un sadales sistēmā". [Online]. [Accessed: 26 June 2020] https://likumi. lv/ta/id/285189-prasibas-biometana-ungazveida-stavokli-parverstas-saskidrinatasdabasgazes-ievadisanai-un-transportesanaidabasgazes-parvades-...

19. Status Review of Renewable Support Schemes in Europe for 2016 and 2017. [Online]. [Accessed: 2 July 2020] https:// www.ceer.eu/documents/104400/-//80ff3127-8328-52c3-4d01-0acbdb2d3bed

20. Bioenergy Europe Statistical Report. Energy Brief: Biogas (2019). [Online]. [Accessed: 8 June 2020] https://bioenergyeurope.org/ article/103-statistical-report-2019-biogas. html

21. Bioenergy Europe. (2019). Statistical Report: Report Biogas. [Online]. [Accessed: 12 May 2020] https://bioenergyeurope.org/ article.html/103

22. Centre on Regulation in Europe. (2019). Future Markets for Renewable Gases and Hydrogen: What Would Be the Optimal Regulatory Provisions? [Online].[Accessed: 8 June 2020] https://www.cerre.eu/sites/ cerre/files/cerre_futuremarketsforrenewab legasesandhydrogen.pdf

23. Renewable Gas Trade Centre in Europe. (2020). Mapping the state of play of renewable gases in Europe. [Online]. [Accessed: 10 July 2020] https://www. regatrace.eu/wp-content/uploads/2020/02/ REGATRACE-D6.1.pdf

24. European Biogas Association. (2020). Biomethane Map. [Online]. [Accessed: 6 July 2020] https://www.europeanbiogas.eu/ wp-content/uploads/2020/06/GIE_EBA BIO_2020_A0_FULL_FINAL.pdf

25. Biomethane Injection Surges in France. (2018). [Online]. [Accessed: 14 June 2020] https://www.bioenergy-news.com/news/ biomethane-injection-surges-in-france/

26. Panorama du gaz renouvelable 2017. [Online]. [Accessed: 9 July 2020] http:// www.grtgaz.com/en/press/press-releases/ news-details/article/panorama-du-gazrenouvelable-2017.html

27. Biomethane. A Renewable Gas that is a Source of Energy. [Online]. [Accessed: 1 July 2020] http://www.grtgaz.com/en/ 
solutions-for-the-future/energy-solutionswith-a-future/biomethane.html

28. The Role of Biomethane towards Decarbonizing the Heat and Transport Sectors. (2019). [Online]. [Accessed: 19 June 2020] https:// actionrenewables.co.uk/news-events/post. php?s=the-role-of-biomethane-towardsdecarbonising-the-heat-and-transportsectors

29. Van Forees, F. (2012). Perspectives for Biogas in Europe. [Online]. [Accessed: 29 June 2020] https://www.oxfordenergy.org/ wpcms/wp-content/uploads/2012/12/NG70.pdf

30. Hengeveld, E. J., Bekkering, J., van Gemert, W. J. T., \& Broekhuis, Antonius A. (2014). When does Decentralized Production of Biogas and Centralized Upgrading and Injection into the Natural Gas Grid Make Sense? Biomass and Bioenergy, 67, 363371. DOI: 10.1016/j.biombioe.2014.05.017

31. Havrysh, V., Nitsenko, V., \& Štreimikienè, D. (2018). Assessment of Optimal Location for a Centralized Biogas Upgrading Facility. Energy \& Environment. DOI:10.1177/ 0958305X18793110

32. Balaman, S. Y. (2019). Decision-Making for Biomass-Based Production Chains: The Basic Concepts and Methodologies. Academic Press.

33. ENTSOG. (2011). Technical Paper on the Injection of Biogas into the Natural Gas Networks. [Accessed: 16 June 2020] https:// www.entsog.eu/sites/default/files/files-oldwebsite/publications/INT\%20Network $\% 20$ Code/2011/INT010-10_Rev4_Paper\%20 on $\% 20$ the $\% 20$ positioning $\% 20$ of\% $\%$ European \%20transporters \%20on\%20 the $\% 20$ injection $\% 20$ of $\% 20$ biogas $\% 20$ into $\% 20$ the $\% 20$ natural $\% 20$ gas $\% 20$ networks.pdf

34. Department of Energy and Climate Change. (2009). Biomethane into the Gas Network: A Guidefor Producers. [Online]. [Accessed:20 May 2020] http://www.organics-recycling. org.uk/uploads/category1060/Biomethane $\% 20$ into $\% 20$ the $\% 20$ Gas $\% 20$ Grid $\% 20$ a\%20Guide $\% 20$ for\%20producers.pdf

35. Zillman, D., Roggenkamp, M., Paddock, L., \& Godden, L. (ed.). (2018). Innovation in Energy Law and Technology: Dynamic Solutions for Energy Transition. Oxford.

36. Hallac, M. (2013). Gas Demand: The Role of Gas-fired Power Plants. In Glachant, J.-M., Hallac, M., \& Vazquez, M. (eds.), Building Competitive Gas Markets in the EU.

37. Commission for Energy Regulation. (2013). Biogas injection into the Natural Gas Grid. Consultation Paper. [Online]. [Accessed: 5 July 2020] https://www.cru. ie/wp-content/uploads/2013/07/cer13209biogas-injection-consultation-paper.pdf

38. Storage and Transportation of Biogas and Biomethane. [Online]. [Accessed: 10 July 2020] http://www.suscon.org/pdfs/news/ biomethane_report/Chapter_4.pdf

39. Zemite, L., Kutjuns, A., Bode, I., Kunickis, M., Zeltins, N. Consistency Analysis and Data Consultation of Gas System of Gas-Electricity Network of Latvia (Open Access), (2018) Latvian Journal of Physics and Technical Sciences, 55 (1), pp. 22-34. Cited 6 times. http://www.degruyter.com/ view/j/lpts.2012.49.issue-5/issue-files/ lpts.2012.49.issue-5.xml, doi: 10.2478/lpts2018-0003

40. Zemite, L., Bode, I., Zeltins, N., Kutjuns, A., Zbanovs, A. Analysis of the Power System Damage Hazard from the Point of View of the Gas Supply System (2018) Proceedings - 2018 IEEE International Conference on Environment and Electrical Engineering and 2018 IEEE Industrial and Commercial Power Systems Europe, EEEIC/I and CPS Europe 2018, art. no. 8494380. Cited 3 times.http://ieeexplore.ieee.org/xpl/most RecentIssue.jsp?punumber $=8476917$, ISBN: 978-153865185-8, doi: 10.1109/ EEEIC.2018.8494380

41. Zemite, L., Kutjuns, A., Bode, I., Kunickis, M., Zeltins, N. Risk Treatment and System Recovery Analysis of Gas System of Gas and Electricity Network of Latvia (Open Access) (2018) Latvian Journal of Physics and Technical Sciences, 55 (5), pp. 3-14. Cited 2 times. http://www.degruyter.com/ view/j/lpts.2012.49.issue-5/issue-files/ lpts.2012.49.issue-5.xml, doi: 10.2478/lpts2018-0031 